\title{
26. LEG 41 SEDIMENT LIPIDS-SEARCH FOR EOLIAN ORGANIC MATTER IN RECENT SAMPLES AND EXAMINATION OF A BLACK SHALE ${ }^{1}$
}

\author{
Bernd R.T. Simoneit, Institute of Geophysics and Planetary Physics, \\ University of California, Los Angeles, California
}

\begin{abstract}
The lipids extracted from samples in the eastern North Atlantic Ocean (Sites 367 and 369) were examined for terrigenous components. The Pliocene samples from both sites contain $n$ alkanes and $n$-fatty acids of mainly allochthonous terrigenous origin with homolog distributions typical of higher plant waxes. This material underwent eolian transport and was preserved under probable anoxic microenvironmental conditions of sedimentation. A Cretaceous black shale, deposited under anoxic conditions, contains lipids derived from both marine and terrigenous sources. Diterpenoids and carbon isotope ratios provide the primary indicators for terrigenous lipids.
\end{abstract}

\section{INTRODUCTION}

Eolian dust carried by the northeast trades from the North African continent falls out over the areas of the DSDP Leg 41 sites. Analyses of the lipids of such dusts have been carried out. The lipids are mainly of plant wax origin (Simoneit and Eglinton, in press; Simoneit, 1975). The lipid distribution patterns of the dusts correlate with similar homolog distributions in the lipids from DSDP core samples in the fallout areas (mainly Site 138-Simoneit and Eglinton, in press; Simoneit, 1975). Thus, it is of interest to examine the lipids of other DSDP sediments with potential dust components in order to determine the areal distribution and depth within a core of such eolian input.

Cretaceous black shales have been encountered in the Atlantic Ocean sediments from various areas. Some of these areas were anoxic basins with high sedimentation rates and large terrigenous components of organic matter (e.g., Simoneit 1977). Therefore, it was of interest to determine if, in the case of the northeastern Atlantic Ocean sediments, the analysis of the lipid matter would allow a distinction to be made between the autochthonous marine and allochthonous terrigenous lipids. It was also of interest to deduce inferences about the environmental conditions of sedimentation.

The samples examined were derived from Sites 367 (located on the eastern edge of the Cape Verde Basin, $12^{\circ} 29.2^{\prime} \mathrm{N}, 20^{\circ} 2.8^{\prime} \mathrm{W}$; water depth: $4748 \mathrm{~m}$ ) and 369 (located on the continental slope off Spanish Sahara $\left(26^{\circ} 35.6^{\prime} \mathrm{N}, 14^{\circ} 59.9^{\prime} \mathrm{W}\right.$; water depth: $\left.1760 \mathrm{~m}\right)$. The Cretaceous black shale is from Site 367 .

'Contribution No. 1607, Institute of Geophysics and Planetary Physics.

\section{EXPERIMENTAL}

The core samples were freeze-dried and then extracted with toluene and methanol (4:1) using ultrasonication. The extracts for each sample were concentrated on a rotary evaporator and subjected to gas chromatographic analysis (GC). The extracts were then treated with diazomethane in ether and subjected to silica gel thin-layer chromatography (TLC) using methylene chloride as eluent. The bands corresponding to hydrocarbons and esters were scraped off the TLC plate after development with iodine vapor, and eluted with ether or ethyl acetate. These fractions were subjected to GC and GC/MS analyses.

The GC analyses were carried out on a HewlettPackard Model 5830 gas chromatograph using a $16 \mathrm{~m}$ $\times 0.75 \mathrm{~mm}$ stainless steel SCOT column coated with OV-101, programmed from $110-280^{\circ} \mathrm{C}$ at $4^{\circ} \mathrm{C} / \mathrm{min}$ using $\mathrm{He}$ carrier gas at a flow rate of $3 \mathrm{ml} / \mathrm{min}$.

The GC/MS analyses were carried out on a DuPont Model 21-492-1 mass spectrometer interfaced directly with a Varian Aerograph Model 204 gas chromatograph equipped with a $10 \mathrm{~m} \times 0.75 \mathrm{~mm}$ glass column which was packed with Gaschrom Q (80-100 mesh) coated with $1 \%$ OV -1 .

The mass spectrometric data was acquired and processed using a DuPont Model 21-094 data system.

The stable isotope analyses were performed using methodology described by Kaplan et al. (1970) and referenced to the standard Chicago PDB.

The porphyrin spectra were obtained on bands separated by the TLC method of Didyk (1975) using UV-visible spectrophotometry.

\section{RESULTS AND DISCUSSION}

The sample descriptions, carbon analyses, and lipid yields are listed in Table 1. 
TABLE 1

Sample Descriptions, Carbon Analyses, and Extract Yields for the Examined Core Sections

\begin{tabular}{|c|c|c|c|c|c|c|c|c|c|c|c|}
\hline \multirow[b]{3}{*}{$\begin{array}{c}\text { Sample } \\
\text { (Interval in } \mathrm{cm} \text { ) }\end{array}$} & \multirow{3}{*}{$\begin{array}{c}\text { Depth } \\
\text { Below } \\
\text { Seabed } \\
(\mathrm{m})\end{array}$} & \multirow[b]{3}{*}{ Lithology } & \multirow[b]{3}{*}{$\begin{array}{l}\text { Geologic } \\
\text { Age }\end{array}$} & \multirow{3}{*}{$\begin{array}{c}\text { Total } \\
\text { Carbon } \\
(\%)^{\mathrm{a}}\end{array}$} & \multirow{3}{*}{$\begin{array}{c}\text { Organic } \\
\text { Carbon } \\
(\%)^{\mathrm{a}}\end{array}$} & \multirow[b]{3}{*}{$\begin{array}{c}\text { Carbonate } \\
(\%)^{\mathrm{a}}\end{array}$} & \multicolumn{4}{|c|}{ Lipid Yields } & \multirow[b]{3}{*}{$\begin{array}{c}\mathrm{Pr} / \mathrm{Ph} \\
\text { (Hydro- } \\
\text { carbons) }\end{array}$} \\
\hline & & & & & & & \multicolumn{2}{|c|}{$n$-alkanes } & \multicolumn{2}{|c|}{$n$-fatty acids } & \\
\hline & & & & & & & $(\mu \mathrm{g} / \mathrm{g})$ & CPI & $\begin{array}{l}\text { Methyl } \\
\text { Esters) }\end{array}$ & CPI & \\
\hline $\begin{array}{l}367-4-3, \\
0-10\end{array}$ & 66.5 & $\begin{array}{l}\text { Foram nanno } \\
\text { marl and clay }\end{array}$ & Pliocene & 4.7 & 0.2 & 37 & 2.7 & 4.0 & 0.06 & 3.6 & 0.7 \\
\hline $\begin{array}{l}367-19-4, \\
10-15\end{array}$ & 649.1 & Black shale & $\begin{array}{l}\text { Cretaceous } \\
\text { (Cenomanian) }\end{array}$ & 11.3 & 9.0 & 18 & 1.7 & 2.9 & 0.4 & 5.3 & 0.3 \\
\hline $\begin{array}{l}369-2-6 \\
135-140\end{array}$ & 11.9 & Nanno marl & Pliocene & 4.6 & 0.1 & 37 & 0.7 & 3.6 & 0.8 & 3.2 & 0.3 \\
\hline
\end{tabular}

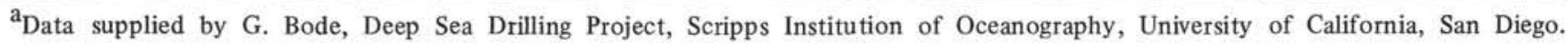

The upper core samples (Sections 367-4-3 and 369-25) are Pliocene age and consist of nanno marl with about $37 \%$ carbonate. The organic carbon contents, as well as the lipid yields, are low. The distribution diagrams for the $n$-alkanes and $n$-fatty acids are shown in Figure 1. The two drill sites are about $2000 \mathrm{~km}$ apart, but the lipid distributions are very similar. The $n$ alkanes exhibit a major distribution maximum at $n-C_{31}$ with a CPI $\approx 4$ for both samples. This maximum is usually associated with higher plant waxes (Simoneit, 1975 , in press a). Similar $n$-alkane distributions were found for eolian dusts presently falling out over this area (Simoneit and Eglinton, in press) and also in other DSDP sediments from this area (Simoneit, 1975). The pristane to phytane ratio for both samples is less than 1.0 , indicating possibly anoxic microenvironmental conditions of sedimentation (Simoneit, 1975).

The $n$-fatty acids exhibited a bimodal distribution with maxima at $n-\mathrm{C}_{16}$ and either $n-\mathrm{C}_{24}$ or $n-\mathrm{C}_{26}$, with a $\mathrm{CPI} \approx 3.5$ for both samples. The maximum at $n-\mathrm{C}_{16}$ could be derived from an autochthonous and/or an allochthonous influx from a continental lacustrine environment. The maxima at $n-\mathrm{C}_{24}$ or $n-\mathrm{C}_{26}$ fatty acid, when considered with the maxima at $n$ - $\mathrm{C}_{31}$ of the $n$ alkanes, are good evidence for higher plant wax (Hitchcock and Nicholls, 1971; Simoneit, 1975). Similar $n$-fatty acid distributions were found for eolian dusts, presently falling out over this area (Simoneit and Eglinton, in press) and also in other DSDP sediments from this area (Simoneit, 1975). The diterpenoid, dehydroabietic acid (Figure 2, Structure I) was found in both of these samples and can be considered a marker of terrigenous resinous plants (Simoneit, in press b). The striking similarity of the lipid homolog distributions for these two samples and the absence of large river influx on the west coast of north Africa indicate an eolian input mechanism for these lipids, with an essentially uniform flux. Thus it appears that eolian fallout of continental dust occurred off the west African coast during the Pliocene. This could be further substantiated by the identification of "Wüstenquarz" in these sediments.

The black shale (Section 367-19-4) is of Cenomanian age and contains $18 \%$ carbonate and $9 \%$ organic carbon. The lipid yield is high and consists predominantly of polar material. The distribution diagrams for the $n$-alkanes and $n$-fatty acids are found in Figure $1 \mathrm{c}$ and $\mathrm{d}$, respectively. The $n$-alkanes are minor components and exhibit a bimodal distribution, maximizing at $n-\mathrm{C}_{17}$ and $n-\mathrm{C}_{31}$ with a $\mathrm{CPI} \approx 2.9$. The maximum at $n-\mathrm{C}_{17}$ may indicate a microbial origin and the higher weight alkanes maximizing at $n-\mathrm{C}_{31}$ indicate a higher plant component (Simoneit, 1975). The phytane is present in a large excess over the pristane $(\mathrm{Pr} / \mathrm{Ph}=0.3)$, indicating strongly anoxic paleoenvironmental conditions, both in the water column and sediment (Didyk et al., in press). The $n$-fatty acids exhibit a bimodal distribution, maximizing at $n$ - $\mathrm{C}_{16}$ and $n$ - $\mathrm{C}_{24}$, with a CPI $\approx 5.3$. This pattern indicates contributions from both autochthonous and allochthonous terrigenous sources, corroborating the results of the $n$-alkanes above. Phytanic acid is present in excess over pristanic acid $(\operatorname{PrA} / \mathrm{PhA} \approx 0.5)$, again indicating an enhancement of the preservation of the $\mathrm{C}_{20}$ isoprenoid due to euxinic paleoenvironmental conditions (Didyk et al., in press). A significant amount of perylene (Figure 2, Structure II) was separated by TLC from the lipid fraction and identified by its UV spectrum and coinjection on glass capillary GC. This compound may be a terrigenous marker (Aizenshtat, 1973), but it has never been found in such old sediments. Other polynuclear aromatic hydrocarbons (other TLC bands that fluoresce under UV) appear to be present in these lipids, which may indicate that these $\mathrm{PAH}$ are alteration products and not primary terrigenous markers.

The cyclic components of the hydrocarbon fraction consist of steroidal and triterpenoidal compounds, with the unsaturated species predominating. The steroids consist of the series $\mathrm{C}_{n} \mathrm{H}_{2}{ }^{-}{ }^{8}$ with $n=27-29$ and lesser amounts of the series $\mathrm{C}_{n} \mathrm{H}_{2 n}{ }^{-}{ }^{6}$ with $n=27-29$. The $\mathrm{C}_{29}$ homolog is the major component of both series. The double bond is located in ring A or B of the monounsaturated series (e.g., Figure 2, Structure III) and the steranes possess the $5 \alpha$-stereochemistry (e.g., Figure 2, Structure IV). The major triterpenoids present consist of two compounds, hop-17(21)-ene (Figure 2, Structure V) and an aromatized triterpenoid-14, 18bisnormethyladianta-13, 15, 17-triene (Figure 3, Structure VI). The former was identified by its mass spectrum on comparison with the standard and coinjection of the standard on capillary GC. The latter 

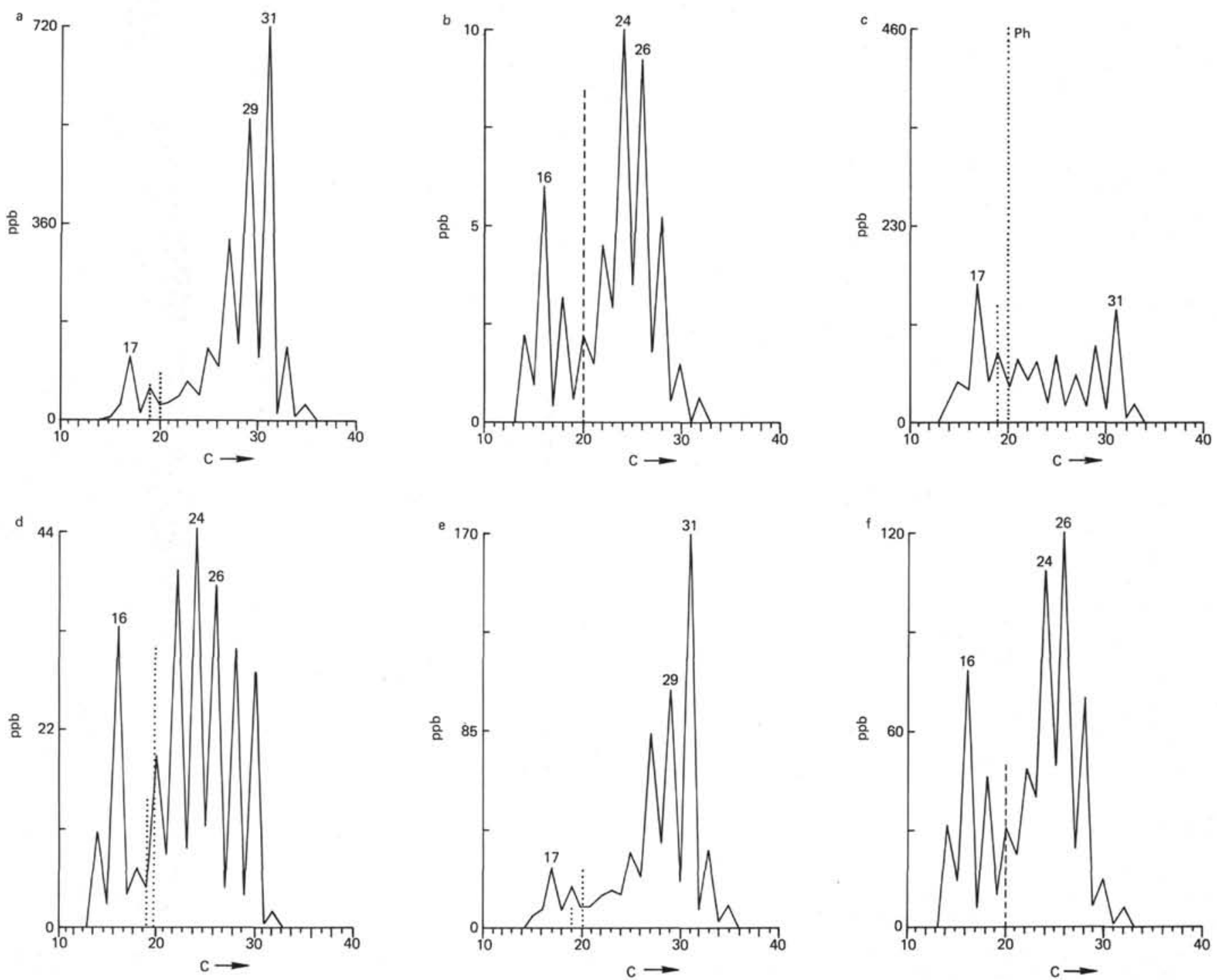

Figure 1. Distribution diagrams for the n-alkanes and n-fatty acids (... . isoprenoids; --diterpenoids). (a) Sample 367-4-3, 0-10 cm (b) Sample 367-4-3 (c) Sample 367-19-4, 10-15 cm (d) Sample 367-19-4 (e) Sample 369-2-5, 135-140 cm (f) Sample 369-2-5.

compound was identified by its mass spectrum on comparison with the synthetic standard (Spyckerelle, 1975). The mass spectrum exhibits the following fragmentation pattern: molecular ion $\left(\mathrm{M}^{+}\right)$at $\mathrm{m} / \mathrm{e} 364$ $\left(\mathrm{C}_{27} \mathrm{H}_{40}\right), \mathrm{M}^{+}-\mathrm{CH}_{3}$ at $\mathrm{m} / \mathrm{e} 349$ (base peak), $\mathrm{M}^{+}-\mathrm{C}_{2} \mathrm{H}_{5}$ at $\mathrm{m} / \mathrm{e} 335$ and intense ions at $\mathrm{m} / \mathrm{e} 225,211,189,145$, and 137. The minor triterpenoids consist of other saturated and monounsaturated homologs of either the hopane and/or moretane series $\left(\mathrm{C}_{\mathrm{n}} \mathrm{H}_{2}{ }_{\mathrm{n}}{ }^{-}{ }_{8}\right.$ for $n=29$ and 30 and $\mathrm{C}_{n} \mathrm{H}_{2 n}{ }^{-} 10$ for $n=30$ to 32 ). The porphyrin content of this sample is less than that reported for a similar sample in the Angola Basin (Simoneit, 1977) and consists mainly of about $4 \mathrm{ppm}$ nickel-DPEP (based on the extract) and about $1.6 \mathrm{ppm}$ vanadyldeoxophylloerythrin. The presence of a significant porphyrin component and an excess of phytane over pristane indicate that the paleoenvironmental conditions in the northeast Atlantic Ocean (Cape Verde Basin) were strongly euxinic (Didyk et al., in press). These conditions are also corroborated by the preliminary core descriptions of Lancelot et al. (1975).
The analyses of the stable carbon isotopes also support a terrigenous input of organic matter to this paleoenvironment. The data for Sample 367-19-4 are total extract $\delta^{13} \mathrm{C}=-27.5^{\circ} / 00$ and kerogen (carbonatefree, extracted residue) $\delta^{13} \mathrm{C}=-28.9^{\circ} \%$. These values are typical of some land plants. They also fall in the range of Cretaceous petroleum, as well as within the mean range of petroleums in general (Degens, 1969). Marine organic matter exhibits more scattered values in the general range of $\delta^{13} \mathrm{C}=-12$ to $-23 \%$ (Degens, 1969).

Contamination from various plasticizers and lubricants is minor and consists primarily of dibutyl and dioctyl phthalates, and dibutyl esters of dicarboxylic acids from the core tubes (Simoneit, 1975).

\section{CONCLUSIONS}

The lipids extracted from Pliocene core samples from the eastern North Atlantic Ocean (Sites 367 and 369) have homolog distributions typical for a terrigenous origin. The allochthonous influx of these lipids appears 
<smiles></smiles>

I. $\mathrm{C}_{20} \mathrm{H}_{28} \mathrm{O}_{2}$

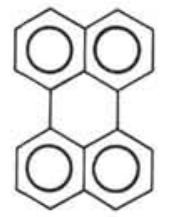

II. $\mathrm{C}_{20} \mathrm{H}_{12}$<smiles>[R]C(CCC(C)C1CCC2C3C=CC4=CC=CCC4(C)C3CCC12C)C(C)C</smiles>

III. $\mathrm{C}_{\mathrm{N}} \mathrm{H}_{2 \mathrm{~N}-8}$

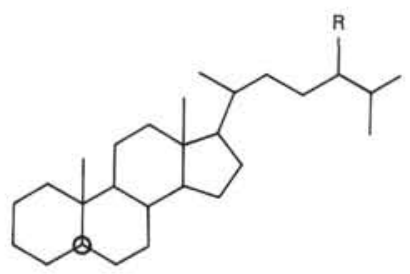

IV. $\mathrm{C}_{\mathrm{N}} \mathrm{H}_{2 \mathrm{~N} \cdot 6}$

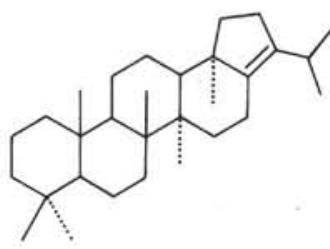

V. $\mathrm{C}_{30} \mathrm{H}_{50}$

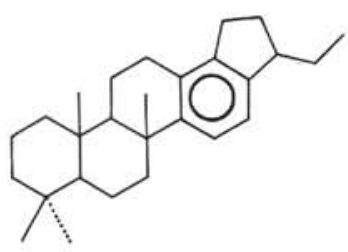

VI. $\mathrm{C}_{27} \mathrm{H}_{40}$

Figure 2. Structure of compounds.

to have been eolian fallout. The lipids reflect the typical higher plant wax distributions, and also contain dehydroabietic acid (I), probably a major marker of resinous higher plants.

The Cretaceous black shale contains lipids with distributions indicative of both marine and terrigenous origin. The depositional environment was a euxinic basin with anoxic bottom waters. Carbon isotope ratio determinations indicate that the bulk of the organic matter is of terrigenous higher plant origin $\left(\delta^{13} \mathrm{C} \approx\right.$ $28 \%$ oo). This appears to be an immature petroliferous sediment.

\section{ACKNOWLEDGMENTS}

I thank the National Science Foundation for making the core samples available, R.P. Philp and S.C. Brown for GC/MS data, D. Winter for stable isotope analysis, and D. Kosiur for porphyrin analyses. Partial financial assistance from the University of Alaska (NOAA Subcontract No. F01770) is gratefully acknowledged.

\section{REFERENCES}

Aizenshtat, Z., 1973. Perylene and its geochemical significance: Geochim. Cosmochim. Acta v. 37, p. 559-567.

Degens, E.T., 1969. Biogeochemistry of stable carbon isotopes. In Organic geochemistry, methods and results: Eglinton, G. and Murphy, M.T.J. (Eds.), Berlin (SpringerVerlag), p. 304-329.

Didyk, B.M., 1975. The geochemistry of petroporphyrins: Ph.D. Thesis, University of Bristol, England.

Didyk, B.M., Simoneit, B.R.T. and Eglinton, G., in press. Geochemical indicators of paleoenvironmental conditions of sedimentation: Nature.

Hitchcock, C. and Nicholls, B.W., 1971. Plant lipid biochemistry: London (Academic Press).

Kaplan, I.R., Smith, J.W., and Ruth, E., 1970. Carbon and sulfur concentration and isotopic composition in Apollo 11 lunar samples. In Proc. Apollo 11 Lunar Sci. Conf.Geochim. Cosmochim. Acta, Suppl. 1, v. 2, Pergamon, p. 1317-1329.

Lancelot, Y., Seibold, E., Cepek, P., Dean, W.E., Eremeev, V., Gardner, J.V., Jansa, L.F., Johnson, D., Krasheninnikov, V., Pflaumann, U., Rankin, J.G., and Trabant, P., 1975. The eastern North Atlantic: Geotimes v. 20, p. 1821.

Simoneit, B.R.T., 1975. Sources of organic matter in oceanic sediments: Ph.D. Thesis, University of Bristol, England. 1977. Lipid analyses of sediments from Site 364 in the Angola Basin. In Initial Reports of the Deep Sea Drilling Project, Volume 40, Bolli, M.H., Ryan, W.B.F., et al. (U.S. Government Printing Office), Washington.

, in press (a). The Black Sea, a sink for terrigenous lipids: Deep-Sea Res.

, in press (b). Diterpenoidal compounds and other lipids in deep-sea sediments and their geochemical significance: Geochim. Cosmochim. Acta.

Simoneit, B.R.T. and Eglinton, G. in press. Organic matter of eolian dust and its input to marine sediments. In Adv. in Organic Geochemistry 1975, Gómez Angulo, J.A. and Campos, R. (Eds.).

Spyckerelle, C., 1975. Thesis: Université Louis Pasteur, Strasbourg, France. 